$\begin{array}{lll}\begin{array}{l}\text { On guard } \\ \text { vigil for West Nile } \\ \text { virus calls on US } \\ \text { chicken flocks } \\ \text { p104 }\end{array} & \begin{array}{l}\text { Patent power } \\ \text { Geneticists face } \\ \text { prospect of paying } \\ \text { to use junk DNA } \\ \text { p105 }\end{array} & \begin{array}{l}\text { Targeted effort } \\ \text { The search for a } \\ \text { therapeutic AIDS } \\ \text { vaccine } \\ p 107\end{array}\end{array}$

\title{
France purges space programme in bid to survive budget crisis
}

\section{Declan Butler, Paris}

In a dramatic bid to address its long-running financial problems, the CNES, France's national space agency, has cut or frozen 10 of its 44 missions - including an ambitious effort to send four landers to Mars.

The agency has struggled over the past five years with falling government funding. Last year, it overspent its $€ 1$.3-billion (US\$1.5-billion) budget by $€ 90$ million.

The rescue plan was announced on 30 April at a press briefing in Paris by Yannick d'Escatha, a former head of the French Atomic Energy Commission who was brought in by president Jacques Chirac to reform the space agency. "We are in a crisis situation," d'Escatha said. "We cannot do everything."

The largest victim of the cuts is NetLander, a French-led mission to Mars. The mission would have dropped four landers on the planet, carrying sensors to study its geophysics, search for water, and record atmospheric conditions. The CNES planned to spend $€ 100$ million on the project, which also involved Finland, Germany, Belgium and Switzerland. In March, NASA shelved plans to contribute $\$ 35$ million to the project.

In addition, the CNES will withdraw its stake in the NASA-led Gamma-ray Large Area Space Telescope (GLAST). Also put on hold are four experiments planned for the International Space Station.

NetLander's collapse marks the demise of an ambitious Franco-American programme of Mars exploration, announced with considerable fanfare in October 2000. The CNES will now support Mars-exploration missions only under the auspices of the European Space Agency (ESA), says d'Escatha.

Space officials on both sides of the Atlantic deny that the loss of these missions is linked to the current political rift between the United States and France. But researchers say that tightbudgets and political tensions are damaging international programmes. "Five years ago there was a strong desire by everybody from the middle levels of NASA up to the White House for increasing international cooperation," says Bruce Banerdt, principal investigator for NetLander at NASA's Jet Propulsion

\section{US Army joins hunt for SARS drug}

Alison Abbott

Researchers at the National Institutes of Health and the US Army have joined forces in a systematic screening programme to find drug candidates to combat severe acute respiratory syndrome (SARS).

The collaboration, which is already under way, was announced at last week's International Conference on Antiviral Research in Savannah, Georgia.

The National Institute of Allergy and Infectious Diseases is collating as many compounds as it can gather that are licensed or in development as antiviral drugs. The US Army Medical Research Institute of Infectious Diseases (USAMRIID) at Fort Detrick, Maryland, will then screen them for activity against the coronavirus thought to cause SARS. In addition, the researchers are screening a commercial library of 400,000 chemicals that are yet to be licensed.

"We hope to run through hundreds of such compounds - or even a thousand very quickly, starting with those already licensed, and working back along the development pipeline," says Robert Baker, a USAMRIID virologist. With luck, he says, the programme could identify agents that will be available for treating SARS within months.

In Europe, meanwhile, antiviral expert Erik De Clercq of the Catholic University of Leuven, Belgium, is taking a different tack. He says he will first identify key points in the biosynthesis of SARS viral RNA that could be targeted by drugs. His group will then evaluate selected compounds from its own chemical library, as well as those submitted by colleagues at other centres. "It's a more 'rational' approach," he says.

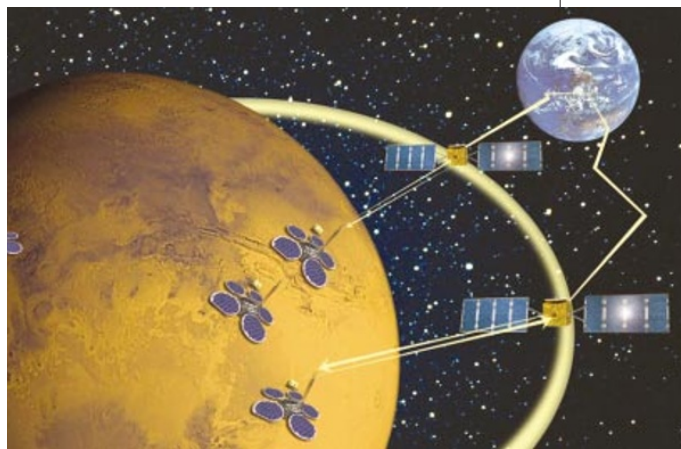

In the red: falling funds have led the French space agency to cancel its NetLander Mars mission.

Laboratory in Pasadena, California. "There is certainly a different atmosphere now."

France's other bilateral space-exploration collaborators have also been hit. The CNES says that it will renegotiate its partnership with India to launch the Megha-Tropiques satellite, to monitor the atmosphere in the tropics. The cuts will spell doom for a proposed Franco-Brazilian atmospheric satellite, and a ground station for the Japanese satellite Alos.

Among missions that have survived are the space telescope Corot, the ocean-surveillance mission Jason-2, and Pléiades, a group of high-resolution Earth-observation satellites.

Researchers are worried, however, that the cuts amount to a downgrading of science at the CNES to pay for other priorities, including supporting the satellite and telecommunications industries, military space programmes and the assurance of Europe's independent access to space aboard the Ariane rocket. The agency's financial health has not been helped by the crisis in the commercial launch market due to a drop in the number of telecoms satellites, and the recent crash of Ariane V (see Nature 420,723; 2002).

D'Escatha has written to NetLander's scientists to suggest that the mission might be saved by incorporating it into ESA's space-science programme, or its Aurora planetary-exploration programme. ButDavid Southwood, ESA's director of science, says that the former option is unlikely within the current budget. A decision on Aurora is unlikely to be taken before next year. 